MEXАНIKA

MECHANICS

https://doi.org/10.15407/dopovidi2021.03.040

УДК 539.3

О.Ю. Чирков, https://orcid.org/0000-0003-1916-0277

В.В. Харченко, https://orcid.org/0000-0002-5795-8792

Інститут проблем міцності ім. Г.С. Писаренка НАН України, Київ

E-mail: chirkale82@gmail.com

\title{
Вплив радіаційної повзучості на визначення формозміни вигородки активної зони реактора ВВEP-1000 за умов довгострокової експлуатації
}

\author{
Представлено академіком НАН України В.В. Харченком
}

Наведено результати аналізу щодо впливу радіаційної повзучості на розрахункову оцінку формозміни вигородки активної зони реактора ВВЕР-1000 за умов довгострокової експлуатації. Застосовано сучасні моделі радіаційного розпухання і радіаційної повзучості, в яких враховується вплив напруженого стану $i$ накопиченої незворотної деформацій на процеси розпухання і повзучості аустенітних сталей, що перебувають під впливом нейтронного опромінення і підвищеної температури. Сформульовано основні положення розрахунку напружено-деформованого стану вигородки та внутрішньокорпусної шахти реактора з урахуванням умов контактної взаємодії. Розрахунковий аналіз виконано у двовимірній постановиі для поперечного перерізу вигородки з максимальною за висотою пошкоджуючою дозою і температурою опромінення за умови узагальненої плоскої деформащії. Дані щодо формозміни вигородки одержано на основі розв'язання зв'язаної контактної задачі залежно від накопиченої пошкоджуючої дози опромінення. Визначення температурного поля $і$ напружено-деформованого стану виконано з урахуванням перерозподілу температури через порушення проєктних умов протоку теплоносія в зоні контакту вигородки з шахтою. Результати розрахунків одержано з використанням медіанних параметрів температурно-дозової залежності радіаційного розпухання аустенітної сталі 08X18Н10Т. Встановлено, що урахування радіаційної повзучості сприяє зниженню рівня напружень, проте збільшує рівень розпухання і переміщення, що додає консерватизму до прогнозної оцінки формозміни вигородки порівняно з даними без урахування радіаційної повзучості.

Ключові слова: реактор ВВЕР-1000, вигородка, внутрішньокорпусна шахта, тепловиділяюча збірка, активна зона, напружено-деформований стан, формозміна вигородки, радіаційне розпухання і радіаційна повзучість, пошкоджуюча доза, метод скінченних елементів.

Одним із вирішальних факторів для обгрунтування умов довгострокової експлуатації енергоблоків AЕС України є прогнозування ресурсу внутрішньокорпусних пристроїв (ВКП) реакторів ВВЕР. Аустенітні хромонікелеві сталі типу 08Х18Н10Т, які використовуються як матеріали ВКП, піддаються в процесі експлуатації інтенсивному нейтронному опромінен-

Ц и т у в а н н я: Чирков О.Ю., Харченко В.В. Вплив радіаційної повзучості на визначення формозміни вигородки активної зони реактора BВЕР-1000 за умов довгострокової експлуатації. Допов. Нац. акад. наук Укp. 2021. № 3. C. 40-47. https://doi.org/10.15407/dopovidi2021.03.040 
ню за температур від 320 до $400^{\circ} \mathrm{C}$, а рівень накопиченої пошкоджуючої дози за час тривалої експлуатації реактора може сягати 100 і більше зсувів на атом (зна). За таких умов матеріали ВКП зазнають радіаційного розпухання і радіаційної повзучості, що може призвести до значної деградації металу і незворотної формозміни такого елемента ВКП, як вигородка.

Основне призначення вигородки полягає в захисті металу корпусу реактора від нейтронного та гамма-випромінювань, що виходять з активної зони реактора. Під час експлуатації вигородка піддається найбільшому впливу нейтронного опромінення, тому що вона розташована в безпосередній близькості від тепловиділяючих збірок (ТВЗ). Протягом проєктного строку служби виїмку вигородки з внутрішньокорпусної шахти реактора не передбачено. Отже, для обгрунтування міцності та розрахункової оцінки формозміни вигородки найбільш актуальним є урахування радіаційних ефектів у металі.

Зазначимо, що прогнозування радіаційного розпухання і радіаційної повзучості металу вигородки є одним з факторів для обгрунтування можливості перевантаження ТВЗ з активної зони реактора, а також контролю величини зазору між вигородкою і шахтою в процесі експлуатації. Змикання вигородки з шахтою внаслідок процесів радіаційного розпухання і радіаційної повзучості металу вигородки може призвести до виникнення контактних напружень, а також перерозподілу витрат теплоносія першого контуру в реакторі та, як наслідок, зміни температурного режиму роботи реактора. Отже, розрахунок напружено-деформованого стану (НДС) та формозміни вигородки в процесі експлуатації - одна 3 основних умов для обгрунтування нормального функціонування реактора в період довгострокової експлуатації енергоблока АЕС.

Нижче наведено результати аналізу щодо впливу радіаційної повзучості на розрахункову оцінку НДС і формозміни вигородки активної зони реактора ВВЕР-1000 після 50 років експлуатації. Розрахунки виконано із використанням сучасних моделей радіаційного розпухання і радіаційної повзучості аустенітних сталей, що перебувають під впливом нейтронного опромінення, високих температур і пошкоджуючої дози, для умов роботи реактора на повній потужності та планового зупинення. Розрахункові дані одержано з урахуванням контактної взаємодії вигородки з шахтою внаслідок перерозподілу температури через порушення проєктних умов теплообміну між вигородкою і шахтою в зоні контакту.

Зазначимо, що в статті авторів [1] наведено результати аналізу НДС та формозміни вигородки, однак без урахування радіаційної повзучості металу. Однак розрахункові дані свідчать про те, що з урахуванням деформацій радіаційної повзучості напруження нижчі, а розпухання та переміщення вищі, що додає консерватизму до прогнозної оцінки формозміни вигородки порівняно з величинами без урахування радіаційної повзучості металу. У [2] містяться результати, одержані з урахуванням радіаційної повзучості, проте з використанням моделей радіаційного розпухання і радіаційної повзучості, в яких не враховується вплив інтенсивності напружень на стиснене розпухання металу вигородки і шахти. У цьому повідомленні наведено результати розрахунків з використанням повної моделі, в якій враховується вплив середнього нормального напруження та інтенсивності напружень на стиснене розпухання і радіаційну повзучість металу вигородки і шахти.

Автори не прагнули повністю охопити всі питання, пов’язані з урахуванням і аналізом чинників, що впливають на розрахункову оцінку НДС і формозміну вигородки в процесі експлуатації. Нижче наведено окремі результати аналізу НДС та формозміни вигородки 3 
урахуванням радіаційного розпухання, радіаційної повзучості та контактної взаємодії вигородки з шахтою за умов довгострокової експлуатації, які, на думку авторів, доповнюють відомі дані інших дослідників і можуть становити інтерес для фахівців у сфері розрахункових методів оцінки міцності та формозміни елементів ВКП реакторів ВВЕР.

1. Математичні моделі радіаційного розпухання і радіаційної повзучості. Залежність величини вільного розпухання $S_{0}$ від пошкоджуючої дози $D$ і температури опромінення $T$ для аустенітної сталі 08X18Н10Т приймали за даними [3] з використанням медіанних параметрів радіаційного розпухання:

$$
S_{0}=c_{D} D^{n} \exp \left(-r\left(T-T_{\max }\right)^{2}\right),
$$

де $T_{\max }=470{ }^{\circ} \mathrm{C}-$ температура максимального розпухання; $c_{D}=1,035 \cdot 10^{-4}$ зна $^{-n} ; n=1,88$; $r=1,825 \cdot 10^{-4}\left({ }^{\circ} \mathrm{C}\right)^{-2}$.

Вплив середнього нормального напруження $\sigma_{m}$, інтенсивності напружень $\sigma_{e q}$ i накопиченої незворотної деформації $q$ на стиснене розпухання $S$ сталі 08X18H10Т визначали за формулою [3]

$$
S=S_{0}\left(1+C_{R}\left((1-\eta) \sigma_{m}+\eta \sigma_{e q}\right)\right) e^{-m q},
$$

де $C_{R}=8 \cdot 10^{-3} \mathrm{MПа}^{-1} ; m=8,75-$ константи матеріалу; $\eta=0,15-$ ваговий множник, за яким визначається ступінь впливу напружень $\sigma_{m}$ та $\sigma_{e q}$ на розпухання $S$.

Залежність сталої швидкості радіаційної повзучості від набору пошкоджуючої дози та розпухання визначали за рівнянням [3]

$$
\frac{d \varepsilon_{e q}^{c}}{d t}=\left(B_{0} \frac{d D}{d t}+\omega \frac{d S}{d t}\right) \sigma_{e q},
$$

де $d \varepsilon_{e q}^{c}-$ інтенсивність приросту деформації повзучості; $t$ - час або будь-який інший параметр, що характеризує зміну навантаження; $B_{0}=10^{-6}(\mathrm{MПа} \cdot 3 н \mathrm{a})^{-1}, \omega=(2,7 . . .3,2) \cdot 10^{-3} \mathrm{MПа}^{-1}-$ константи матеріалу, які слабо залежать від температури; $d D / d t$ - швидкість набору пошкоджуючої дози; $d S / d t$ - швидкість розпухання.

Значення коефіцієнтів у рівняннях стисненого розпухання і радіаційної повзучості одержано за допомогою обробки експериментальних даних опромінених зразків для різних температур, пошкоджуючих доз опромінення та видів напруженого стану [3].

2. Основні положення методики розрахунку. Визначальні рівняння, що дають змогу описувати неізотермічні процеси непружного деформування з урахуванням стисненого розпухання і радіаційної повзучості металу від впливу пошкоджуючої дози та температури опромінення, сформульовані та математично обгрунтовані в [4]. Ці рівняння використовували в розрахунках НДС вигородки і шахти з урахуванням залежності кривих деформування від накопиченої пошкоджуючої дози і температури опромінення. Для умов розвантаження враховували незворотність деформацій радіаційного розпухання і радіаційної повзучості.

Для розрахунку температурного поля враховували неоднорідний розподіл внутрішніх енерговиділень, зумовлених поглинанням гамма-квантів і нейтронів, а також умови охолодження зовнішніх поверхонь і каналів вигородки. 
Вплив радіаційної повзучості на деформування опроміненого металу враховували перетворенням кривої пружно-пластичного деформування шляхом зсуву всіх їі точок на ділянці зміцнення, у тому числі границю пропорційності, на величину приросту деформації повзучості за етап навантаження.

В основу розрахункового аналізу НДС вигородки і шахти покладено змішану схему методу скінченних елементів (MCE), яка забезпечує безперервну апроксимацію як для переміщень, так і для напружень та деформацій, що дає змогу визначати НДС з високим ступенем точності. Реалізацію чисельного алгоритму розв’язання задачі радіаційної повзучості проводили з використанням процедури поетапного навантаження в поєднанні з методом пружних розв'язків на основі змішаної схеми МСЕ [4].

Під час аналізу контактної взаємодії вигородки з шахтою враховували номінальний зазор і різні умови контакту (проковзування, тертя, зчеплення). На початковому етапі розрахунку НДС задавали передбачувану зону контакту, межі якої уточнювали в процесі розв’язання контактної задачі методом послідовних наближень. Нерівномірний розподіл температури та НДС визначали розв’язанням зв'язаної контактної задачі радіаційної повзучості з урахуванням об’ємних деформацій стисненого розпухання. Між контактуючими поверхнями вигородки і шахти задавали ідеальний теплообмін, а за межами зони контакту моделювали умови конвективного теплообміну. Взаємовплив температурного поля і НДС на розрахункове визначення зони контакту вигородки з шахтою враховували за допомогою ітераційного процесу, в якому граничні умови теплообміну і контактної взаємодії уточнювали за допомогою багаторазового розв’язання задачі теплопровідності та контактної задачі радіаційної повзучості до досягнення заданої точності визначення зони контакту.

3. Розрахункові моделі. Розрахунки НДС виконано у двовимірній постановці для поперечного перерізу з максимальною за висотою вигородки пошкоджуючою дозою і температурою опромінення за умови узагальненої плоскої деформації. У такій постановці осьова деформація приймається сталою за висотою вигородки, і додатковим рівнянням для їі визначення є умова рівноваги, яка полягає в рівності нулю інтеграла осьових зусиль, розподілених на верхньому торці вигородки.

Зазначимо, що використання двовимірної розрахункової моделі значно спрощує розв’язання зв'язаної контактної задачі, яка враховує перерозподіл температури і НДС у зоні контакту вигородки з шахтою, тому що для знаходження границі контакту достатньо врахувати зміну граничних умов теплообміну і контактної взаємодії лише за кутовою координатою. Загалом для визначення поверхні контакту вигородки з шахтою необхідно враховувати зміну температурного поля і НДС не тільки вздовж кутової координати, а й за висотою вигородки.

Для одержання адекватних результатів аналізу контактної взаємодії вигородки з шахтою застосовували розрахункову модель, в якій ці елементи ВКП розглядали спільно як одне тіло з номінальним зазором.

4. Розрахунковий аналіз НДС вигородки. Як вихідні дані для розрахунку НДС і формозміни вигородки використовували відомі розподіли пошкоджуючої дози і температури опромінення вигородки і шахти реактора ВВЕР-1000, які побудовано за даними [5]. Розрахункові дані одержано із використанням моделі стисненого розпухання, в якій враховується вплив напруженого стану та накопичених незворотних деформацій. Контактну 


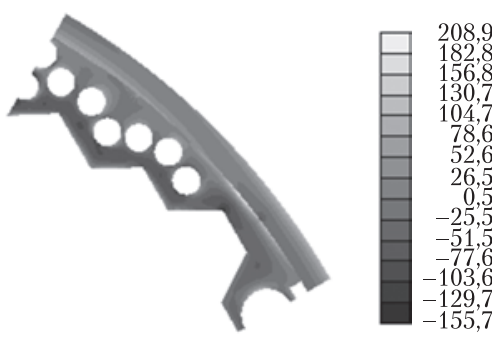

$a$

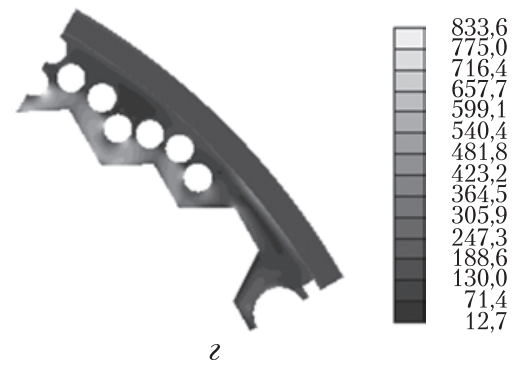

Puc. 2. Розрахункові розподіли розпухання вигородки (\%) після 50 років експлуатації: $a-3$ урахуванням радіаційної повзучості; б - без урахування радіаційної повзучості

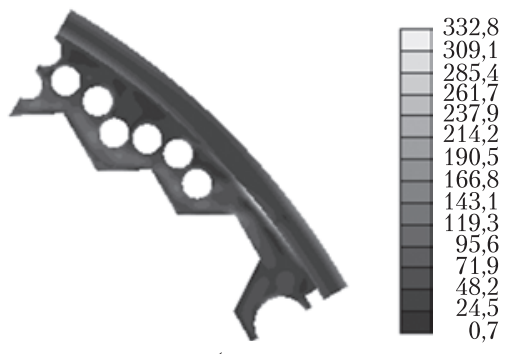

6
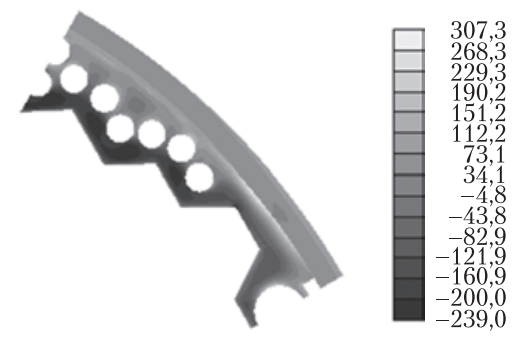

B

Puc. 1. Розрахункові розподіли напружень (МПа) для умов роботи реактора на повній потужності після 50 років експлуатації: $a, \sigma-$ з урахуванням радіаційної повзучості; в, $\imath-$ без урахування радіаційної повзучості. $a$, $в$ - середнє нормальне напруження; 6,2 - інтенсивність напружень
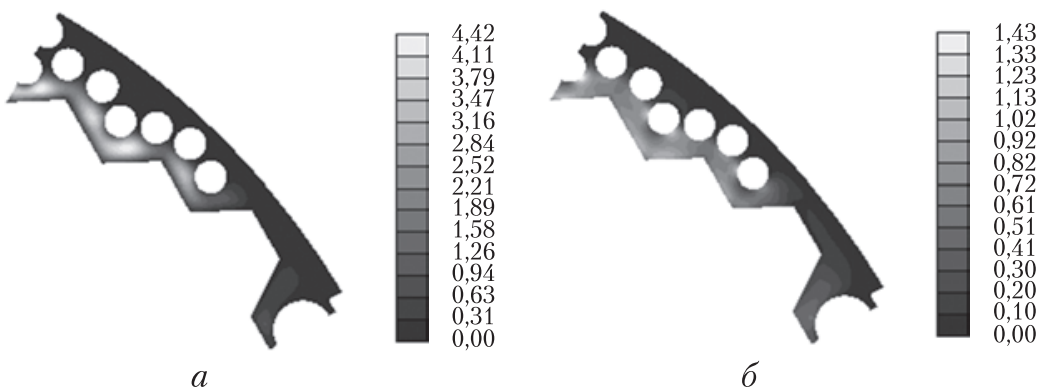

взаємодію вигородки з шахтою моделювали з урахуванням початкового номінального зазору 2,5 мм за умови вільного ковзання.

На рис. 1 зіставлено результати визначення середнього нормального напруження та інтенсивності напружень у вигородці і шахті для умов роботи реактора на повній потужності після 50 років експлуатації, розраховані з урахуванням і без урахування радіаційної повзучості. 3 огляду на кругову симетрію вигородки і шахти результати розрахунків наведено для ㄲï 12-ї частини з центральним кутом 30.

Порівняльний аналіз наведених розподілів напружень з даними, одержаними без урахування радіаційної повзучості, свідчить про помітне зниження рівня розрахункових напружень. Найбільш істотне зниження спостерігається для інтенсивності напружень. Отже, неврахування радіаційної повзучості призводить до завищеного рівня розрахункових напружень.

5. Розрахунковий аналіз формозміни вигородки. На рис. 2 наведено дані із визначення радіаційного розпухання вигородки після 50 років експлуатації, розраховані з урахуванням і без урахування радіаційної повзучості.

На рис. 3, 4 зіставлено дані про розподіл вздовж колової координати радіального зазору між вигородкою і шахтою, а також залишкового зазору між гранями вигородки і периферійними ТВЗ у напрямку спільної нормалі, які розраховано з урахуванням номінальних 


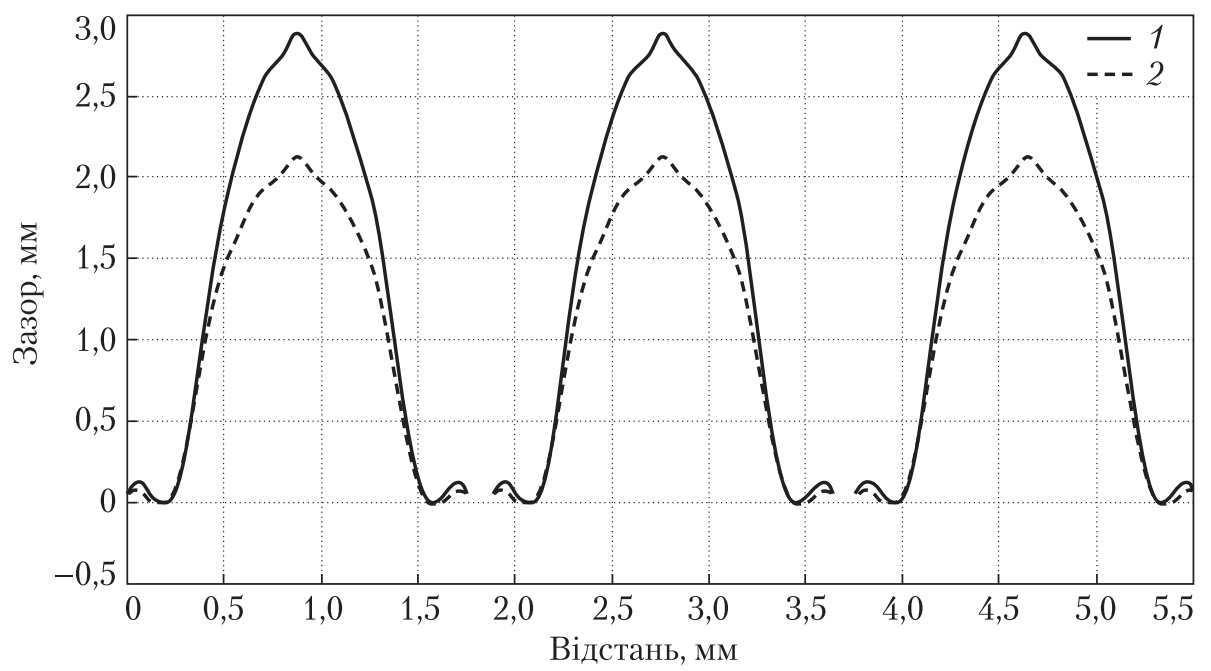

Puc. 3. Порівняння радіального зазору між вигородкою і шахтою для умов роботи ректора на повній потужності після 50 років експлуатації: 1 - з урахуванням радіаційної повзучості; 2 - без урахування радіаційної повзучості

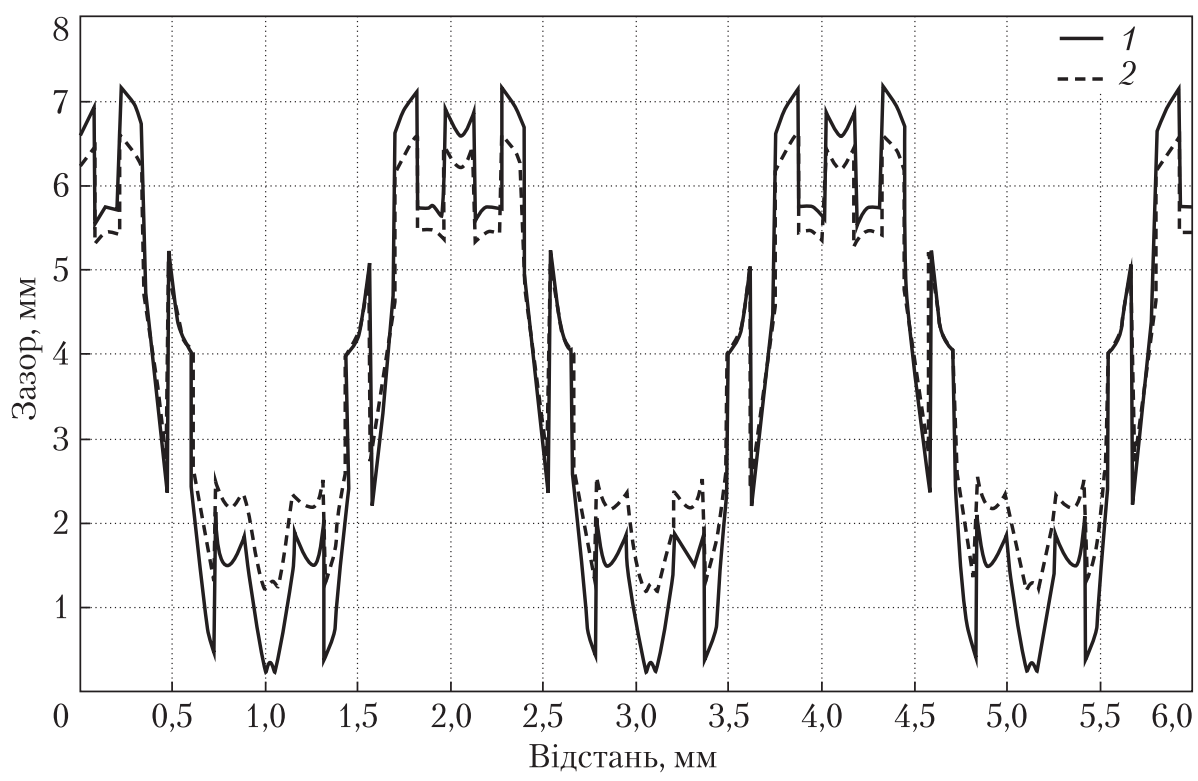

Puc. 4. Порівняння залишкового зазору між гранями вигородки та дистанцінуючими решітками периферійних ТВЗ після 50 років експлуатації: 1 - 3 урахуванням радіаційної повзучості; 2 - без урахування радіаційної повзучості

зазорів 2,5 і 4 мм відповідно за умови, що розміри активної зони після зупинення реактора відповідають початковим значенням. Відлік відстані на графіках ведеться вздовж колової координати зовнішньої поверхні вигородки від найбільшого отвору охолоджуючого каналу проти годинникової стрілки на величину кута $180^{\circ}$.

Згідно з розрахунковими даними мінімальні значення зазору між вигородкою і шахтою мають локальний характер в області розташування отвору поздовжнього охолоджую- 
чого каналу з найбільшим діаметром і паз-каналу для протоку теплоносія між вигородкою і шахтою. За результатами розрахунків очікується, що під час експлуатації реактора в понадпроєктний період може мати місце локальний контакт вигородки з шахтою в області розташування каналу з найбільшим отвором і паз-каналу. Локальна зона контакту розташована симетрично відносно умовної прямої, що ділить отвір каналу на дві рівні частини, їі місце розташування відповідає куту $\pm 7^{\circ}$ щодо цієї прямої.

У разі врахування радіаційної повзучості рівень розпухання більший, що зумовлено нижчим рівнем напружень стискання в області, прилеглій до внутрішньої поверхні вигородки. Рівень напружень з урахуванням радіаційної повзучості нижчий, а переміщень вищий порівняно з результатами розрахунку без урахування повзучості. Розрахунки напружень свідчать про зниження максимальних значень приблизно в 1,5-2,4 раза. Істотне зниження напружень спостерігається для інтенсивності напружень та головних напружень.

Мінімальний зазор між вигородкою і шахтою для обох розрахунків знаходиться приблизно на одному рівні, проте врахування радіаційної повзучості призводить до більш консервативної оцінки мінімального залишкового зазору. За умови радіаційної повзучості залишковий зазор між гранями вигородки та периферійними ТВЗ значно менший, ніж зазор без урахування повзучості, проте забезпечується для медіанної залежності розпухання протягом 50 років експлуатації.

Отже, врахування радіаційної повзучості сприяє зниженню рівня розрахункових напружень, проте збільшує рівень розпухання та переміщення, що призводить до більш консервативної прогнозної оцінки формозміни вигородки порівняно з даними без урахування повзучості.

\section{ЦИТОВАНА ЛІТЕРАТУРА}

1. Чирков А.Ю., Харченко В.В. Особенности расчетной оценки формоизменения выгородки активной зоны реактора ВВЭР-1000 с учетом радиационного распухания. Пробл. прочности. 2020. № 3. С. 5-20.

2. Чирков О.Ю., Харченко В.В., Кравченко В.І., Кобельский С.В. Розрахункова оцінка формозміни вигородки реактора ВВЕР-1000 в процесі експлуатації. Ядерна та радіаційна безпека. 2020. № 3. С. 13-20. https://doi.org/10.32918/nrs.2020.3(87).02

3. Марголин Б.З., Мурашова А.И., Неустроев В.С. Анализ влияния вида напряженного состояния на радиационное распухание и радиационную ползучесть аустенитных сталей. Пробл. прочности. 2012. № 3. C. $5-24$.

4. Чирков О.Ю. Радіаційна повзучість у задачах механіки непружного деформування матеріалів та елементів конструкцій. Київ: Інститут проблем міцності ім. Г.С. Писаренка НАН України, 2020. 160 с.

5. Margolin B., Fedorova V., SorokinA. et al. The mechanisms of material degradation under neutron irradiation for WWER internals and methods for structural integrity assessment. Structural integrity and life of NPP equipment: Proceedings of the International Conference (Kyiv, 2-5 Oct. 2012). Kyiv, 2012.

Надійшло до редакції 26.03.2021

\section{REFERENCES}

1. Chirkov, A. Yu. \& Kharchenko, V. V. (2020). Special features of computational assessment of the change in shape of WWER-1000 reactor core baffle in view of irradiation-induced swelling. Strength Mater., 52, pp. 339352. https://doi.org/10.1007/s11223-020-00184-9

2. Chirkov, A., Kharchenko. V., Kravchenko. V. \& Kobelsky, S. (2020). Assessment of WWER-1000 core baffle form alteration during operation. Nucl. Radiat. Saf., No. 3, pp. 13-20 (in Ukrainian). https://doi.org/10.32918/ nrs.2020.3(87).02 
3. Margolin, B. Z., Murashova, A. I. \& Neustroiev, V. S. (2012). Analysis of the influence of type stress state on radiation swelling and radiation creep of austenitic steels. Strength Mater., 44, pp. 227-240. https://doi.org/ 10.1007/s11223-012-9376-3

4. Chirkov, A. Yu. (2020). Radiation creep in problems of mechanics of inelastic deformation of materials and structural elements. Kyiv: G. S. Pisarenko Institute for Problems of Strength of the NAS of Ukraine (in Ukrainian).

5. Margolin, B., Fedorova, V., Sorokin, A. et al. (2012, October). The mechanisms of material degradation under neutron irradiation for WWER internals and methods for structural integrity assessment. Proceedings of the International Conference Structural integrity and life of NPP equipment, Kyiv.

Received 26.03.2021

O.Yu. Chirkov, https://orcid.org/0000-0003-1916-0277

V.V. Kharchenko, https://orcid.org/0000-0002-5795-8792

G.S. Pisarenko Institute of Problems of Strength of the NAS of Ukraine, Kyiv

E-mail: chirkale82@gmail.com

\section{RADIATION CREEP EFFECT ON THE FORM CHANGE DETERMINATION OF WWER-1000 REACTOR CORE BAFFLE UNDER LONG-TERM OPERATION}

The paper presents the results of the analysis of the irradiation creep effect on the calculated assessment of the form change in the WWER-1000 reactor core baffle under long-term operation. The modern models of radiation-induced swelling and radiation creep are used. They consider the effect of the stressed state and accumulated irreversible strains on the processes of swelling and creep in austenite steels under the neutron irradiation and elevated temperature. The basic tenets of the calculation of the stress-strain state in the core baffle and invessel reactor barrel considering the contact interaction are stated. The calculation analysis is performed in the two-dimensional statement for a cross-section of the core baffle with the maximum (by height) damaging dose and irradiation temperature under the generalized plane strain conditions. The data on a form change in the core baffle are obtained using the solution to the mixed contact task depending on the accumulated damaging irradiation dose. The determination of the temperature field and stress-strain state was made considering the temperature redistribution due to the violation of the design conditions of the heat carrier flow within the contact zone between the core baffle and barrel. The calculation results are determined using the median parameters of the temperature-dose dependence of the free swelling in $08 \mathrm{Kh} 18 \mathrm{~N} 10 \mathrm{~T}$ austenite steel. It is shown that the consideration of the radiation creep facilitates the stress level reduction, however, it increases the swelling and displacement that makes the prediction assessment of the core baffle form change more conservative as compared with the data without considering the radiation creep.

Keywords: WWER-1000 reactor, core baffle, in-body mine, fuel assembly, core, stress-strain state, change in shape of core baffle, radiation swelling and radiation creep, damaging dose, method of finite elements. 